\title{
Decreased Binding of Dopamine D3 Receptors in Limbic Subregions after Neonatal Bilateral Lesion of Rat Hippocampus
}

\author{
Gonzalo Flores, David Barbeau, Rémi Quirion, and Lalit K. Srivastava \\ McGill Center for Research in Schizophrenia, Douglas Hospital Research Center, Department of Psychiatry, McGill \\ University, Montréal, Québec, Canada H4H $1 R 3$
}

Neonatal, bilateral lesion of the ventral hippocampus (NH) in rats recently has been proposed as a model of schizophrenia because these animals show postpubertal hypersensitivity to stress and to dopamine (DA) agonists that can be reversed by neuroleptic treatment. In search of the mechanisms of postpubertal emergence of hyperdopaminergic behavior in this model, we investigated developmental expressions of DA D1, D2, and D3 receptors in various striatal and limbic subregions of rats that had received bilateral ibotenic acid lesion of the $\mathrm{VH}$ at postnatal day 7 (PD7). D-Amphetamine-, apomorphine-, and stress-induced changes in locomotor activity were measured and, in accordance with previous reports, we observed an increased locomotor activity at PD56 in the hippocampallesioned group. The expression of DA D1, D2, and D3 receptors was then estimated in these rats by ligand autoradiography at PD41 and PD62. We observed that the levels of DA D3 recep- tors, as measured by tritiated 7-hydroxy-N,N-di-n-propyl-2amino-tetralin $\left(\left[{ }^{3} \mathrm{H}\right] 7-\mathrm{OH}-\mathrm{DPAT}\right)$ binding, are markedly reduced at PD62 in the limbic areas of lesioned rats compared with sham controls, particularly in the nucleus accumbens, olfactory tubercles, and islands of Calleja. A small but significant increase in D1 receptors was also seen in the caudate-putamen of the lesioned animals at PD62, whereas no significant change in the overall expression of D2 receptors $\left(\left[{ }^{3} \mathrm{H}\right]\right.$ spiperone binding) was noted. In view of the inhibitory role of $D 3$ receptors on locomotion and, presumably, other DA-mediated behaviors, it is suggested that behavioral changes in the neonatally hippocampal-lesioned rats may be mediated by altered D3 receptor levels.

Key words: hippocampus; schizophrenia; animal model; D3 receptors; nucleus accumbens; islands of Calleja; dopamine receptor; neurodevelopment
Accumulating evidence suggests that at least some forms of schizophrenia could have their origin in a putative early neurodevelopmental defect (Wcinberger, 1987; Roberts, 1991; Bloom, 1993; Bogerts, 1993) that presumably alters the cytoarchitecture of temporal lobe structures (Arnold et al., 1991; Conrad et al., 1991; Akbarian et al., 1993a; Jakob and Beckmann, 1994; Barbeau et al., 1995, Goldsmith and Joyce, 1995) and other limbic brain areas (Benes et al., 1991; Akbarian et al., 1993b). It is suggested that such changes may result in impaired connectivities between prefrontal and temporolimbic brain regions (Weinberger et al., 1992), and dysregulation of various neurotransmitter systems including dopamine (DA) (for review, see Davis et al., 1991; Shapiro, 1993). Clinical features of schizophrenia typically appear in early adulthood (Marengo, 1994), are exacerbated by D-amphetamine (Janowski et al., 1973) and stressful life events (Joseph et al., 1979) and, in a majority of cases, and can be controlled by neuroleptic drugs acting as DA D2-like receptor blockers (Schwartz et al., 1993; Sunahara et al., 1993). Accordingly, bilateral excitotoxic ventral hippocampal $(\mathrm{VH})$ damage in the neonatal rat [postnatal day 7 (PD7)] has been proposed as an animal model of

\footnotetext{
Received Nov. 9, 1995; revised Dec. 15, 1995; accepted Dec. 27, 1995.

This study was supported by a grant from the Medical Research Council of Canada (MRC) to L.K.S. G.F. and D.B. are recipients of postdoctoral fellowships from the Consejo National de Cicncia y Tecnologia of Mexico and from the MRC, respectively. R.Q. is a Chercheur-Boursier de Mérite Exceptionel, and I.K.S. is a Chercheur-Boursier Senior 1 of the Fonds de la Recherche en Santé du Québec. We are grateful to Drs. Dominique Walker and Joseph Rochford, Douglas Hospital Research Centre, for their assistance with surgery and behavioral testing, respectively. We thank Dr. Jin Jun Liang for his expert technical assistance.

Correspondence should be addressed to Dr. Lalit K. Srivastava, Douglas Hospital Research Centre, Neuroscience Division, 6875 LaSalle Boulevard, Verdun, Québec, Canada, H4H 1R3.

Copyright 1996 Socicty for Neuroscience $0270-6474 / 96 / 162(120-07 \$ 05.00 / 0$
}

schizophrenia because it results in the development of hypersensitivity to stress, and to direct (apomorphine) or indirect (Damphetamine) DA agonists, that appears only after puberty (Lipska and Weinberger, 1993, 1995; Lipska et al., 1993). Thesc phenomena are thought to involve an alteration of the mesolimbic and mesostriatal dopaminergic transmission and can be normalized by neurnleptic treatments (Lipska and Weinberger, 1994).

The DA receptors are classified in two broad families, namely the D1-like (D1 and D5) and D2-like (D2, D3, and D4) receptors (for review, see Niznik and VanTol, 1992; Sibley and Monsma, 1992; Gingrich and Caron, 1993). Both the D1 and the D2 receptors are abundantly expressed and widely distributed throughout striatal and limbic $\mathrm{D} \Lambda$ fields including the nucleus accumbens and the olfactory tubercle. Stimulation of the D1-like receptors increases the oral stereotypic behaviors but has little direct influence on the locomotor activity (Mittleman et al., 1993), whereas activation of the D2-like receptors with the agonist quinpirole results in a marked increase in locomotion (Eilman and Szechtman, 1989). The recently cloned D3 receptor is predominantly expressed in limbic areas, such as the nucleus accumbens, olfactory tubercles, and the islands of Calleja of rat and human brains (Lévesque et al., 1992; Landwehrmeyer et al., 1993; Murray et al., 1994; Booze and Wallace, 1995). In contrast to prototypic D2 antagonists, D3 receptor-preferring antagonists increase spontaneous locomotor activity and potentiate locomotion induced by D-amphetamine or apomorphine administration in rats (Waters et al., 1993). In addition, a putative D3 agonist, 7-hydroxy- $N, N$-di$n$-propyl-2-amino-tetralin (7-OH-DPAT), decreases the spontaneous locomotor behaviors in rats (Svensson et al., 1994).

We hypothesized that long-term changes in the levels of striatal 
and/or limbic DA receptors could underly the behavioral consequences of an early lesion of the VH. Therefore, we have investigated by quantitative autoradiography the status of pre- and postpubertal levels of D1-like, D2-like, and D3 DA receptor subtypes in this purported animal model of schizophrenia.

\section{MATERIALS AND METHODS}

Materials. Ibotenic acid, apomorphine hydrochloride, ketanserin, butaclamol, GTP, and DA were purchased from Research Biochemicals (Natick, MA). D-Amphetamine sulfate and 1,3-di(2-5-tolyl)guanidine (DTG) were obtained from Sigma (St. I ouis, MO). $\left[{ }^{3} \mathrm{H}\right] \mathrm{SCH} 23390$ (70 $\mathrm{Ci} / \mathrm{mmol}$ ) was obtained from DuPont NEN (Boston, MA), and $\left[{ }^{3} \mathrm{H}\right]$ spiperone $(104 \mathrm{Ci} / \mathrm{mmol}),\left[{ }^{3} \mathrm{H}\right] 7-\mathrm{OH}-\mathrm{DPAT}(139 \mathrm{Ci} / \mathrm{mmol}),{ }^{3} \mathrm{H}$ Hyperfilm, and microseale tritium standards were purchased from $\Lambda$ mersham Canada (Toronto, Ontario, Canada). 2-Methyl-butane was purchased from BDH Chemicals (Montréal, Québec, Canada), and EDTA was from Boehringer Mannheim (Laval, Québec, Canada). Gelatin was from Fisher Scientific (Montréal, Québec, Canada), and bovine serum albumin was from Calbiochem (La Jolla, CA). All other chemicals were of analytical reagent grade quality and were obtained from commercial sources.

Animals. Pregnant Sprague-Dawley rats were obtained at gestational day 14-17 from Charles River Canada (St. Constant, Qućbcc, Canada). Animals were individually housed in a temperature- and humiditycontrolled environment on a $12 \mathrm{hr}$ ligh1/dark cycle with free access to standard laboratory chow and tap water until time of delivery. The day after birth, litters of 6-10 male pups were formed, and on PD7, corresponding to a body weight of $15-17 \mathrm{gm}$, each pup was assigned to either the sham $(n=12)$ or the lesioned $(n=16)$ group. All surgical procedures described in this study have been approved previously by the McGill University Animal Care Committee in accordance with the guidelines of the Canadian Council for Animal Care.

Surgery. The method described by Lipska et al. (1993) was followed with minor modifications. First, anesthesia by hypothermia was obtained by putting the pups on wet ice for $10-15 \mathrm{~min}$. The pups were then positioned and taped on a platform, which was fixed to a stereotaxic Kopf instrument (Stoelting, Wood Dale, IL). An incision was made over the skull, and $0.3 \mu \mathrm{l}$ of ibotenic acid $(5 \mu \mathrm{g} / \mu \mathrm{l})$ or an equal volume of the vehicle (0.1 M PBS, pH 7.4) was injected in each VH over a 2 min period through a 30 -gauge stainless steel cannulae positioned at the following coordinates: AP $-3.0 \mathrm{~mm}, \mathrm{ML} \pm 3.5 \mathrm{~mm}$ to bregma, and VD $-5.0 \mathrm{~mm}$ from dura. The cannulae remained in place for 4 min after completion of the infusion. After this procedure, pups were placed under a warming lamp for recovery and then returned to their mothers. At PD21, animals were weaned, grouped two or three per cage, and housed as described above.

Behavioral testing. Four (PD35) or seven weeks (PD56) after the surgery, the locomotor activity of sham-operated ( $n=6$ per age group) and ibotenic acid-lesioned ( $n=8$ per age group) rats was assessed in 2-photocell activity boxes connected to an IBM computer equipped with software (Actanal) developed by Concordia University (Montréal, Québec, Canada). The locomotor activity of each animal was assessed under four testing conditions. (l) After exposure to a novel environment: unacelimatized rats were placed in an activity box for a $60 \mathrm{~min}$ period while the locomotor activity score was recorded. (2) After D-amphetamine injection: after record of locomotion in a novel environment, animals were kept in the activity boxes, injected first with $1 \mathrm{ml} / \mathrm{kg}$ $0.9 \% \mathrm{NaCl}$ (s.c.) and 60 inin later with a $1 \mathrm{mg} / \mathrm{ml}$ solution of D-ampletamine sulfate dissolved in $0.9 \% \mathrm{NaCl}(1 \mathrm{mg} / \mathrm{kg}$ free base, s.c.), and the focomotor activity was recorded for the next 180 min. (3) After a swim stress test: the next day, animals were placed in a $26^{\circ} \mathrm{C}$ water-filled pool for a $15 \mathrm{~min}$ period. After the swim test, animals were immediatcly transferred to the activity boxes where their locomotor activity seore was recorded over the next 120 min. (4) After apomorphine injection: Seventy-two hours after the swim stress test, animals were placed in the activity boxes where they were kept for a 60 min habituation period followed by a subcutaneous injection of $1 \mathrm{ml} / \mathrm{kg} 0.1 \%$ ascorbic acid $/ 0.9 \%$ saline solution. One hour later, they were injected with a $1 \mathrm{mg} / \mathrm{ml}$ solution of apomorphine dissolved in $0.1 \%$ ascorbic acid $/ 0.9 \%$ saline $(0.5 \mathrm{mg} / \mathrm{kg}$ free base, s.c.), and the locomotor activity was subsequently recorded for

Table 1. Quantitative analysis of the levels of D1-like, D2-like, and D3 dopamine receptors in the striatum and limbic areas of the rat brain after neonatal bilateral hippocampus lesion

\begin{tabular}{|c|c|c|c|c|c|c|}
\hline \multirow[b]{2}{*}{ PD41 } & \multicolumn{2}{|c|}{$\begin{array}{l}\text { D1-like } \\
\left(\left[{ }^{3} \mathrm{H}\right] \mathrm{SCH} 23390\right)\end{array}$} & \multicolumn{2}{|c|}{$\begin{array}{l}\text { D2-like } \\
\text { (['3]spiperone) }\end{array}$} & \multicolumn{2}{|c|}{$\begin{array}{l}\text { D3 } \\
\left(\left[{ }^{3} \mathrm{H}\right] 7 \cdot \mathrm{OH}-\mathrm{DP} \wedge \mathrm{T}\right)\end{array}$} \\
\hline & $\begin{array}{l}\text { Sham } \\
(n=3)\end{array}$ & $\begin{array}{l}\text { Lesion } \\
(n=3)\end{array}$ & $\begin{array}{l}\text { Sham } \\
(n=3)\end{array}$ & $\begin{array}{l}\text { Lesion } \\
(n=3)\end{array}$ & $\begin{array}{l}\text { Sham } \\
(n=6)\end{array}$ & $\begin{array}{l}\text { Lesion } \\
(n=7)\end{array}$ \\
\hline CP-dorsolateral & $373 \pm 14.6$ & $378 \pm 11.9$ & $187 \pm 1.4$ & $186 \pm 5.9$ & $2.0 \pm 0.2$ & $1.4 \pm 0.3$ \\
\hline CP-dorsomedial & $358 \pm 7.5$ & $368 \pm 9.9$ & $157 \pm 3.1$ & $146 \pm 4.5$ & $2.4 \pm 0.2$ & $1.6 \pm 0.4$ \\
\hline $\mathrm{CP}$-ventral & $384 \pm 13.9$ & $378 \pm 8.2$ & $140 \pm 7.3$ & $140 \pm 7.6$ & $3.9 \pm 0.2$ & $2.5 \pm 0.3$ \\
\hline Fundus-CP & $400 \pm 12.3$ & $399 \pm 15.5$ & $118 \pm 6.2$ & $116 \pm 11.1$ & $6.2 \pm 0.4$ & $3.8 \pm 0.2$ \\
\hline Nucleus accumbens-core & $369 \pm 6.9$ & $354 \pm 8.4$ & $102 \pm 5.7$ & $98 \pm 8.8$ & $10.3 \pm 0.6$ & $6.2 \pm 0.5^{*}$ \\
\hline Nucleus accumbens-shell & $375 \pm 9.1$ & $377 \pm 9.4$ & $73 \pm 5.5$ & $84 \pm 10.5$ & $12.0 \pm 0.8$ & $7.5 \pm 0.9^{* *}$ \\
\hline Olfactory tubercle & $349 \pm 7.9$ & $339 \pm 13.8$ & $77 \pm 9.5$ & $97 \pm 14.0$ & $10.2 \pm 0.7$ & $6.5 \pm 0.7^{*}$ \\
\hline Islands of Calleja & n.d. & n.d. & n.d. & n.d. & $34.6 \pm 0.6$ & $31.2 \pm 1.3$ \\
\hline PD62 & $\begin{array}{l}\text { Sham } \\
(n=3)\end{array}$ & $\begin{array}{l}\text { Lesion } \\
(n=4)\end{array}$ & $\begin{array}{l}\text { Sham } \\
(n=3)\end{array}$ & $\begin{array}{l}\text { Lesion } \\
(n=4)\end{array}$ & $\begin{array}{l}\text { Sham } \\
(n=6)\end{array}$ & $\begin{array}{l}\text { Lesion } \\
(n=8)\end{array}$ \\
\hline CP-dorsolateral & $293 \pm 3.8$ & $340 \pm 10.0^{* * *}$ & $180 \pm 8.0$ & $193 \pm 6.9$ & $1.4 \pm 0.3$ & $1.2 \pm 0.3$ \\
\hline CP-dorsomedial & $283 \pm 3.4$ & $325 \pm 10.0^{* * *}$ & $151 \pm 5.9$ & $155 \pm 2.8$ & $1.8 \pm 0.4$ & $1.3 \pm 0.3$ \\
\hline CP-ventral & $307 \pm 4.2$ & $344 \pm 2.9^{*}$ & $134 \pm 7.0$ & $144 \pm 2.8$ & $2.7 \pm 0.4$ & $1.8 \pm 0.4$ \\
\hline Fundus- $\mathrm{CP}$ & $328 \pm 6.8$ & $364 \pm 6.1^{*}$ & $112+9.1$ & $120 \pm 16.3$ & $4.6 \pm 0.8$ & $2.2 \pm 0.4$ \\
\hline Nucleus accumbens-core & $325 \pm 10.4$ & $345 \pm 15.3$ & $97 \pm 10.8$ & $101 \pm 7.4$ & $7.2 \pm 0.6$ & $3.0 \pm 1.2^{*}$ \\
\hline Nucleus accumbens-shell & $326 \pm 12.0$ & $338 \pm 10.5$ & $8.5 \pm 11.2$ & $99+8.2$ & $9.7+0.8$ & $3.6 \pm 0.7^{* *}$ \\
\hline Olfactory tubercle & $278 \pm 9.8$ & $303 \pm 4.3$ & $73 \pm 9.7$ & $74 \pm 8.9$ & $9.0 \pm 1.0$ & $3.7 \pm 0.6^{*}$ \\
\hline Islands of Callcja & n.d. & n.d. & n.d. & n.d. & $34.6 \pm 1.6$ & $17.6 \pm 2.5^{* *}$ \\
\hline
\end{tabular}

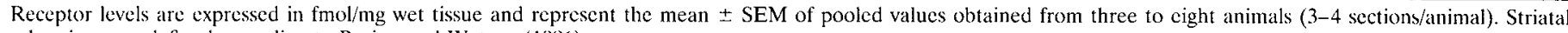
subregions are defined according to Paxino and Watson (1986).

$p<0.05$.

$p<0.01$. CP, Caudate-putamen; n.d., not determined. 
$120 \mathrm{~min}$. Data were analyzed by a two-way ANOVA with lesion status and age as independent factors ( $p<0.05$ was considered significant).

Brain processing. Rats were killed by rapid decapitation $48 \mathrm{hr}$ after the last testing day, namely either at PD41 or at PD62, brains were rapidly removed, frozen in a 2 -methyl-butane/dry ice mixture $\left(-40^{\circ} \mathrm{C}\right)$, and then stored at $-80^{\circ} \mathrm{C}$ until use. Frozen rat brains were sectioned at $15 \mu \mathrm{m}$ thickness on the coronal plane using a Leitz cryostat. Sections were collected on precleaned, gelatin-coated microscope slides ( 3 sections/ slide), thaw-mounted, desiccated under vacuum at $4^{\circ} \mathrm{C}$ overnight, and then stored at $-80^{\circ} \mathrm{C}$ until the day of the experiment. For assessment of lesion size, serial sections at the level of hippocampus were stained with $0.5 \%$ cresyl violet and examined under microscope where lesions and probe placement could be visualized.

Receptor autoradiography. Brain sections taken at the level of the caudate-putamen and nucleus accumbens (plate 10-12 of the atlas of Paxinos and Watson, 1986) were used in the following protocols. For D1-like and D2-like receptor binding, sections were first preincubated for $10 \mathrm{~min}$ at room temperature in $50 \mathrm{~mm}$ Tris- $\mathrm{HCl}$, pH 7.4, containing 154 $\mathrm{mm} \mathrm{NaCl}, 1 \mathrm{~mm}$ EDTA, and $0.1 \%$ bovine serum albumin. Sections were then incubated for $90 \mathrm{~min}$ at room temperature in the same buffer containing either $2 \mathrm{nM}\left[{ }^{3} \mathrm{H}\right] \mathrm{SCH} 23390(74 \mathrm{Ci} / \mathrm{mmol}$; for D1-like receptor binding) or $1 \mathrm{nM}\left[{ }^{3} \mathrm{H}\right]$-spiperone $(104 \mathrm{Ci} / \mathrm{mmol}$; for $\mathrm{D} 2$-like receptor binding). Ketanserin (30 nM) was added in each case to mask possible binding of ligands to serotonergic $5-\mathrm{HT}_{2}$ sites. For both D1 and D2 autoradiography, nonspecific binding was determined on adjacent brain sections by adding $1 \mu \mathrm{M}(+)$-butaclamol in the binding buffer. Incubations were terminated by dipping the slides in ice-cold buffer followed by two consecutive 10 min washes in the same buffer. After a final dipping in ice-cold distilled water, slides were dried at room temperature and apposed to ${ }^{3} \mathrm{H}$-labeled Hyperfilm for $5-10 \mathrm{~d}$, alongside microscalecalibrated tritium standards.

$\left[{ }^{3} \mathrm{H}\right] 7-\mathrm{OH}-\mathrm{DPAT}$ binding to the D3 receptor was assessed following the procedure of Lévesque et al. (1992) with minor modifications. Tissue sections were first preincubated for $30 \mathrm{~min}$ in $50 \mathrm{~mm}$ Tris- $\mathrm{HCl}, \mathrm{pH} \mathrm{7.4}$, containing $120 \mathrm{mM} \mathrm{NaCl}$ and $300 \mu \mathrm{M}$ GTP. Sections were then incubated for $2 \mathrm{hr}$ at room temperature with $2 \mathrm{~nm}\left[{ }^{3} \mathrm{H}\right] 7-\mathrm{OH}-\mathrm{DPAT}, 50 \mathrm{~mm}$ Tris- $\mathrm{HCl}, \mathrm{pH} 7.4,40 \mathrm{mM} \mathrm{NaCl}, 300 \mu \mathrm{M}$ GTP, and $5 \mu \mathrm{M}$ DTG (to block binding to sigma site). DA $(1 \mu \mathrm{M})$ was used to determine nonspecific labeling. Incubations were terminated by washing the brain sections twice for $10 \mathrm{~min}$ each in ice-cold $50 \mathrm{~mm}$ Tris-HCl, pH 7.4. After a brief dipping in ice-cold distilled water, brain sections were rapidly dried and apposed to ${ }^{3} \mathrm{H}$ Hyperfilm for 4 weeks. The autoradiograms were analyzed using a computerized image-analysis system (MCID-4, Imaging Research, St. Catherines, Ontario, Canada). The binding data were analyzed in brain subregions according to Paxinos and Watson (1986), namely the caudateputamen dorsolateral, dorsomedial, and ventral, the fundus striatum, and the shell and core of the nucleus accumbens. In addition, binding in the olfactory tubercles and the islands of Calleja was also analyzed (Table 1). Comparison between groups was done by applying two-way ANOVA with lesion and age as independent variables $(p<0.05$ was considered significant).

\section{RESULTS}

\section{Verification of the lesion}

Neonatally lesioned animals show bilateral reduction in the size of the hippocampus (Fig. 1). Cresyl violet-stained sections obtained from neonatally lesioned animals at PD41 and PD62 reveal a significant bilateral damage of the $\mathrm{VH}$ with neuronal loss, atrophy, and apparent retraction of the hippocampal formation. Cavities resulting from the lesion were also occasionally seen. In all VH-lesioned animals, the dorsal-anterior portion of the hippocampal formation was spared. In one brain included in the study, the lesion extended to the adjacent entorhinal cortex.

\section{Behavioral testing}

The prepubertal (PD35) and postpubertal (PD56) effects of the neonatal $\mathrm{VH}$ lesion on locomotor activity in a novel environment are illustrated in Figure $2 A$. In both age groups, either in sham or in lesioned animals, active exploratory behavior was the initial response of rats placed in a novel environment. Whereas no difference in novelty induced locomotor activity was seen between

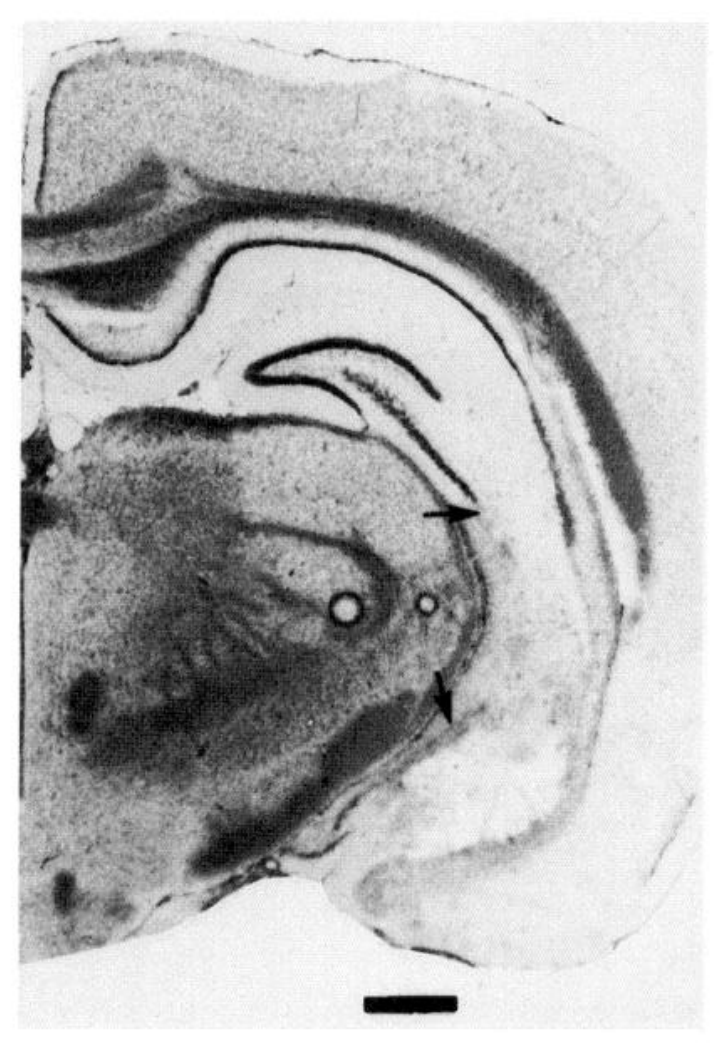

Figure 1. Representative Nissl-stained section of the hippocampus of a VH-lesioned PD62 animal illustrating the effect of lesion performed as described in Materials and Methods. The top arrow indicates an area where disruption of the normal hippocampal anatomy is clearly visible. The bottom arrow shows a cavity surrounded by gliosis in the ventral portion of the hippocampus. Notice the normal appearance of the dorsal part of the hippocampus. Scale bar, $1 \mathrm{~mm}$.

sham and lesion groups at PD35, a significant increase in the exploratory behavior was clearly observed at PD56 in the lesioned group $\left(F_{(3,24)}=6.73, p=0.0019\right)$. Similarly, an enhanced locomotor activity score was observed in PD56 VH-lesioned animals after a $15 \mathrm{~min}$ swim period $\left(F_{(3,24)}=10.32, p=0.0001\right.$; Fig. $\left.2 B\right)$.

Injection of $\mathrm{D}$-amphetamine induced a marked increase in locomotor activity in PD35 and PD56 animals. However, whereas the effect of D-amphetamine on locomotion was similar between the sham and lesioned groups at PD35, it was significantly potentiated in PD56 VH-lesioned animals $\left(F_{(3,24)}=9.50, p=0.0003\right.$; Fig. $2 C$ ). Similarly, apomorphine stimulatory effect on locomotor activity is potentiated only in PD56 VH-lesioned animals $\left(F_{(3,24)}\right.$ $=11.45, p<0.0001$; Fig. 2D).

\section{$\left[{ }^{3} \mathrm{H}\right] \mathrm{SCH} 23390$ binding}

D1-like receptors as measured by $\left[{ }^{3} \mathrm{H}\right] \mathrm{SCH} 23390$ binding are distributed throughout the dorsal and the ventral part of the striatum. D1 receptor levels in the area of study are slightly lower at PD62 (280-365 fmol/mg) than at PD41 (350-400 fmol/mg) in both sham and lesioned groups, and there appears to be an age-related decline in D1 receptors. Neonatal VH-lesioned animals show no significant difference in D1 receptor binding at PD35 when compared with sham-operated animals. However, when both group are compared at PD56, a small (15\%) but significant increase in D1 receptor density is observed in the caudate-putamen and the fundus striatum of lesioned animals $\left(F_{(15,36)}=13.69, p<0.0001 ;\right.$ Table 1$)$. 
A

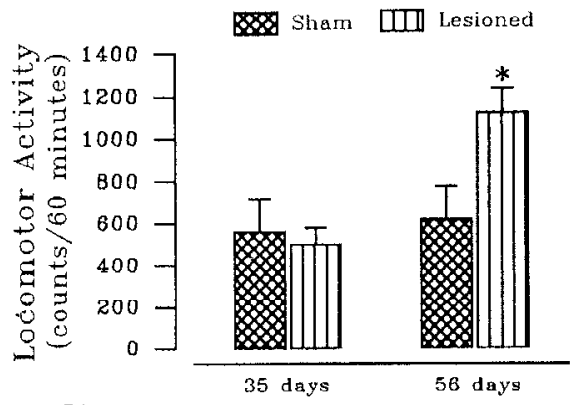

(

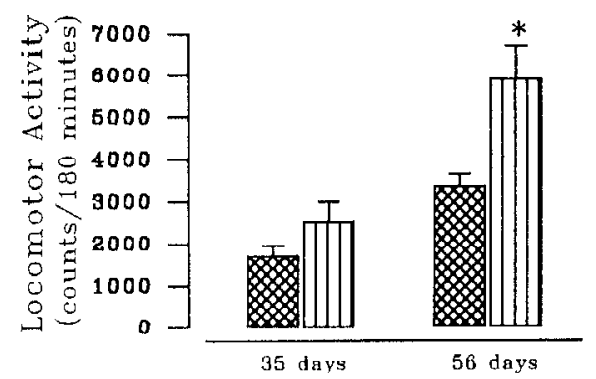

\section{$\left[{ }^{3} \mathrm{H}\right]$ spiperone binding}

$\left[{ }^{3} \mathrm{H}\right]$ spiperone labels DA receptor subtypes belonging to the D2like family (D2, D3, and D4). D2-like receptor density shows a dorsoventral density gradient maximal in the caudate-putamen region $(150-180 \mathrm{fmol} / \mathrm{mg}$ ). The distribution and the density of D2-like binding sites do not differ significantly between the shamoperated and VH-lesioned animals (Table 1).

\section{[3 $\mathrm{H}] 7-\mathrm{OH}-\mathrm{DPAT}$ binding}

DA D3 receptors, measured by $\left[{ }^{3} \mathrm{H}\right] 7-\mathrm{OH}$-DPAT binding, were found principally in the islands of Calleja, the olfactory tubercle, and the nucleus accumbens (I'able 1, Fig. 3). Because the $K_{d}$ of $\left[{ }^{3} \mathrm{H}\right] 7-\mathrm{OH}-\mathrm{DPAT}$ for D3 receptors has been reported to be $0.7-$ $1.0 \mathrm{~nm}$ (Levesque et al., 1992), our binding data obtained at a $2 \mathrm{~nm}$ concentration of the radioligand would be consistent with a change in the $B_{\max }$ of the receptor rather than an altered $K_{\mathrm{d}}$. A low level of D3 receptor expression was also detected in the striatum, particularly in its medial portion (1-5 fmol/mg). Compared with sham controls, the VH-lesioned animals show a significant decrease in D3 receptor levels in the striatal and limbic subregions (Fig. 3, Table 1). The significant decrease in D3 receptor levels is already present in PD41 animals (approximately $-40 \%$ ), but it is more pronounced in the PD62 group (approximately $-60 \%$ ), particularly in D3 receptor-rich areas such as the nucleus accumbens, the olfactory tubercle, and the islands of Calleja $\left(F_{(15,92)}=87.81, p<0.0001\right)$.

\section{DISCUSSION}

The major aim of the present study was to evaluate the pre- and postpubertal levels of D1-like, D2-like, and D3 dopaminergic receptors in rats that had undergone a bilateral ibotenic acid lesion of the $\mathrm{VH}$ at PD7. We report here that this procedure induces major reductions in the level of D3-binding sites in the nucleus accumbens, olfactory tubercle, and the islands of Calleja that are already apparent at PD41 but become more significant by PD62. A small but significant increase in D1-like receptor density was also present in the caudate-putamen, but only at PD62. In contrast, the overall expression of the D2-like receptors did not change significantly after neonatal VH lesioning.

The behavioral consequences of the neonatal VH lesion were characterized as described previously (Lipska and Weinberger, 1993; Lipska et al., 1993). Neonatal VH lesioning resulted in a stressinduced hyperlocomotion appearing only by PD56. This observation does not depend on the paradigm used for testing (either novelty or swim stress) and is in agreement with previous results (Lipska and Weinberger, 1993; Lipska et al., 1993). Neonatal lesioning of the VH also potentiated the locomotor effects of D-amphetamine at PD56, whereas no difference was detected at PD35. Similarly, apomorphine-induced hyperlocomotion was clearly potentiated in PD56 VH-lesioned animals, whereas only a trend $(p<0.06)$ toward a significant increase in locomotor activity was observed when tested at PD35. It was reported previously that the amphetamine-induced hypersensitivity was apparent only at PD56, whereas apomorphineinduced increases in locomotor activity were potentiated in lesioned animals at both PD35 and PD56 (Lipska and Weinberger, 1993). Except for this small discrepancy, behavioral data reported here are in accordance with these earlier results.

The anatomical distribution and relative density of D3-binding sites observed in the present study are similar to previous reports using $\left[{ }^{3} \mathrm{H}\right] 7-\mathrm{OH}-\mathrm{DPAT}$ or other radioligands (Gelhert et al., 1992; Lévesque et al., 1992; Booze and Wallace, 1995). 7-OHDPAT has also been shown to possess some affinity for sigma sites (Schoemaker, 1993; Wallace and Booze, 1995). Accordingly, we have added a saturating dose of the selective sigma blocker DTG (Wallace and Booze, 1995) in our assays. It would appear, therefore, that the observed distribution of $\left[{ }^{3} \mathrm{H}\right] 7-\mathrm{OH}-\mathrm{DPAT}$-binding sites represents principally D3 and not sigma receptors. Experiments with in situ hybridization to assay receptor mRNAs would be necessary to evaluate whether the changes in receptor binding are reflections of reduced synthesis or some post-transcriptional modification. 


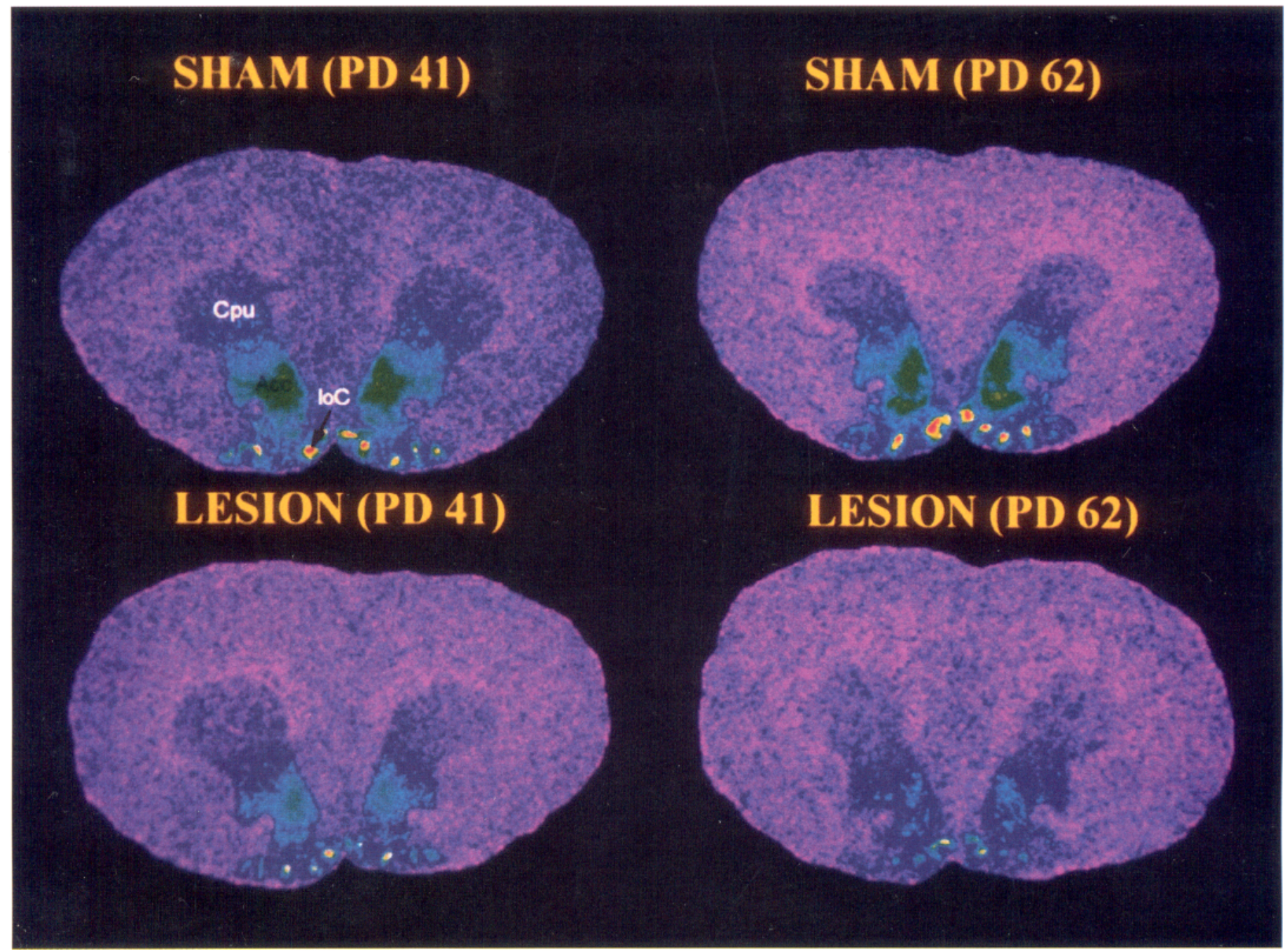

Figure 3. Photomicrograph of $\left[{ }^{3} \mathrm{H}\right] 7-\mathrm{OH}-\mathrm{DPAT}$ binding to D3 receptors in the brains of sham-operated or VH-lesioned animals killed at PD41 or PD62. The binding is highest in the shell of the nucleus accumbens $(A c c)$ and in the island of Calleja (IoC), whereas only low amounts of D3 sites are seen in the caudate-putamen $(\mathrm{Cpu})$, particularly in its medial portion. Neonatal hippocampal lesions induced important decrease in D3 binding levels in most striatal subregions examined. This decrease is more apparent at PD62 than at PD41 (see Table 1 for quantitative data).

Neonatal $\mathrm{VH}$ lesioning reduced the expression of D3 receptors in all brain regions studied. However, the greatest decrements were observed in the limbic structures such as the nucleus accumbens, the olfactory tubercle, and the islands of Calleja. Reductions in D3 receptors, already present at PD41 but highly accentuated by PD62 after neonatal VH lesion, correlate well with the trend of a hyperdopaminergic behavior present in this model before and after puberty (Lipska et al., 1993) (this study). Recent studies have suggested that the role of D3 receptors in locomotor behavior may be opposite to that of the D2 receptor subtype. For example, D3 receptor antagonists tend to enhance the locomotor effects of DA agonists, whereas the D2 blockers are well known to inhibit it (Waters et al., 1993, 1994). It is believed, therefore, that change in locomotor activity induced by DA agonists represents the outcome of a balance between their combined activity at the D2 and D3 receptors. Pharmacological evidence has suggested that D3 receptors could act as autoreceptors modulating DA synthesis and/or release (Meller et al., 1993; Tang et al., 1994). However, recent data obtained with a preferential D3 receptor antagonist, U99194A, show that the inhibitory action of D3 receptors on locomotor activity likely occurs via a postsynaptic mechanism and is independent of change in DA release (Waters et al., 1994). Thus, decreased expression of D3 receptors, especially the pronounced decrease observed at PD62, would lead to an unopposed stimulation of D2 receptors by DA agonists (apomorphine) or by DA itself released either by stress or pharmacologically (D-amphetamine). In support of this hypothesis, it has been demonstrated that D-amphetamine-induced locomotor activity seen after the blockade of D3 receptors can be reversed by raclopride, a selective D2 antagonist (Waters et al., 1993). Taken together, these observations support the critical importance of changes in the levels of D3 receptors as one of the molecular mechanisms underlying the long-term behavior changes observed after neonatal $\mathrm{VH}$ damage.

Reductions in the level of D3-binding sites in the nucleus accumbens and the islands of Calleja could explain, at least partly, the hyperdopaminergic behavior observed in PD56 animals after a neonatal VH lesion. However, it is likely that other mechanisms and systems may be involved as well. In fact, the small but significant increase of D1-like receptor sites in the caudateputamen might also participate in the hyper-responsive behaviors expressed by these $\mathrm{VH}$-lesioned animals through its synergistic 
action on D2-mediated functions (Clark and White, 1987; Mittleman et al., 1993). The involvement of presynaptic mechanisms could also be suspected in view of the observation of an increased release of DA in the nucleus accumbens after lesions of the VH in adult rats (Lipska et al., 1992; Wilkinson et al., 1993). Further studies will be necessary to verify these various aspects in the model used here.

The mechanism(s) by which a neonatal VH lesion induces a decrease in the level of D3 receptors in the nucleus accumbens, the olfactory tubercle, and the islands of Calleja, and a small increase in D1 receptors in the dorsal striatum of PD62 VHlesioned animals, is not clear at this time. The receptor changes described in this study are either the consequence of a loss of direct VH projections to these structures (nucleus accumbens is one such structure that receives direct glutamatergic projections from the hippocampus), or they are related to neurodevelopmental disturbances in other brain regions (possibly the prefrontal cortex) secondary to an early destruction of the $\mathrm{VH}$, a hypothesis that has been proposed to explain the stress hyper-responsivness shown in this animal model (Lipska and Weinberger, 1993; Lipska et al., 1993). It is also possible that the changes in D3 binding in the lesioned animals could be a result of previous drug treatments, stress, or both that may interfere with lesion in unique ways to affect $\mathrm{D} 3$ binding. We have preliminary results that stress by itself does not influence D3 binding in intact rats (A. P. Park and L. S. Srivastava, unpublished data). However, it has been shown recently that prenatal stress in rats induces long-lasting changes in DA receptors in the nucleus accumbens, mainly a decrease in D3 receptors (Henry et al., 1995).

Much evidence points toward subtle anatomical defects in the hippocampus of schizophrenic subjects that may be of developmental origin (Arnold et al., 1991; Conrad et al., 1991; Jakob and Beckmann, 1994; Barbcau et al., 1995; Goldsmith and Joyce, 1995). In addition, principally because of the clinical efficacy of neuroleptic drugs in ameliorating some of the psychotic symptoms, the dopaminergic system has long been implicated in schizophrenia (Davis et al., 1991). The present study provides a basis that links the early disruption of the hippocampal formation with long-term changes in levels of DA receptor subtypes that presumably underly the hyperdopaminergic behaviors observed in this putative animal model of schizophrenia. At present, there is speculation regarding the role of D3 receptors in schizophrenia. This is essentially based on the primary limbic distribution of the D3 receptor subtype in rat and human brains (Landwehrmeyer et al., 1993; Murray et al., 1994) as well as its affinity for typical and atypical neuroleptics (Sunahara, 1992; Schwartz et al., 1993). A recent report of reduced D3 mRNA in schizophrenic brains (Schmauss et al., 1993) further supports the potential implication of this DA receptor subtype in this disorder. In view of the inhibitory influence of the $\mathrm{D} 3$ receptor on $\mathrm{D} 2$ receptor-mediated behaviors, it is tempting to speculate that dopaminergic dysfunctions suspected to occur in schizophrenia may result from an attenuated D3 receptor tone.

\section{REFERENCES}

Akbarian S, Viñuela A, Kim II, Perkin SC, Bunney WE, Jones EC (1993a) Distorted distribution of nicotinamide-adenine dinucleotide phosphate-diaphorase neurons in temporal lobe of schizophrenics implies anomalous cortical development. Arch Gen Psychiatry 50:227-230. Akbarian S, Bunney Jr WE, Potkin SG, Wigal SB, Hagman JO, Sandman CA, Jones EG (1993b) Altered distribution of nicotinamide-adenine dinucleotide phosphate-diaphorase cells in the frontal lobe of schizo- phrenics implies disturbance of cortical development. Arch Gen Psychiatry 50:169-177.

Arnold SE, Lee VMY, Gur ER, Trojanowski JQ (1991) Abnormal expression of two microtubule associated proteins (MAP2 and MAP5) in specific fields of the hippocampal formation in schizophrenia. Proc Natl Acad Sci USA 88:10850-10854.

Barbeau D, Liang JJ, Robitaille Y, Quirion R, Srivastava LK (1995) Decreased expression of the embryonic form of the cell adhesion molecule in schizophrenic brains. Proc Natl Acad Sci USA 92:2785-2789.

Benes FM, McSparren J, Bird ED, San Giovanni J, Vincent S (1991) Deficits in small interneurons in prefrontal and cingulate cortices of schizophrenic and schizoaffective patients. Arch Gen Psychiatry 48:996-1001.

Bloom FF (199.3) Advancing a neurodevelnpmental origin for schizophrenia. Arch Gen Psychiatry 50:224-227.

Bogerts B (1993) Recent advances in the neuropathology of schizophrenia. Schizophrenia Bull 19:431-445.

Booze RM, Wallace DR (1995) Dopamine D2 and D3 receptors in the rat striatum and nucleus accumbens: use of 7-OH-DPAT and $\left[{ }^{125} \mathrm{I}\right]$ iodosulpiride. Synapse 19:1-13.

Clark D, White FJ (1987) D1 dopamine receptor-the search for a function: a critical evaluation of D1/D2 dopamine receptor classification and its functional implications. Synapse 1:347-388.

Conrad AJ, Abebe T, Austin R, Forsythe S, Scheibel AB (1991) Hippocampal pyramidal cell disarray in schizophrenia as a bilateral phenomenon. Arch Gen Psychiatry 40:413-417.

Davis KL, Kahn RS, Ko G, Davidson M (1991) Dopamine in schizophrenia: a review and reconceptualization. Am J Psychiatry 148:1474-1485.

Eilman D, Szechtman H (1989) Biphasic effects of D-2 agonist quinpirole on locomotion and movements. Eur J Pharmacol 161:151-157.

Gohlert DR, Gackenheimer SL, Seenlan P, Sclatus J (1992) Autoradiographic localization of $\left[{ }^{3} \mathrm{H}\right]$ quinpirole to dopamine D2 and D3 receptors in the rat brain. Eur J Pharmacol 211:189-194.

Gingrich JA, Caron MG (1993) Recent advances in the molecular biology of dopamine receptors. Annu Rev Neurosci 16:299-321.

Goldsmith SK, Joyce JN (1995) Alterations in hippocampal mossy fiber pathway in schizophrenia and Alzheimer's disease. Biol Psychiatry $37: 122-126$

Henry C, Guegan G, Cador M, Arnauld E, Arsaut J, Le Moal M, Demotes-Mainard J (1995) Prenatal stress in rats facilitates amphetamine-induced sensitization and induces long-lasting changes in dopamine receptors in the nucleus accumbens. Brain Res 685:179-186.

Jakob H, Beckmann H (1994) Circumscribed malformation and nerve cell alterations in the entorhinal cortex of schizophrenics: pathogenetic and clinical aspects. J Neural Transm 98:83-106.

Janowski DS, El-Youset MK, Davis JM, Sekerke KJ (1973) Provocation of schizophrenic symptoms by intravenous administration of methylphenidate. Arch Gen Psychiatry 28:185-191.

Joseph MH, Frith CD, Waddington JL (1979) Dopaminergic mechanism and cognitive deficits in schizophrenia. Psychopharmacology (Berl) 63:273-280.

Landwehrmeyer B, Mengod G, Palacios JM (1993) Dopamine D3 receptor mRNA and binding sites in human brain. Mol Brain Res 18:187-192.

Lévesque D, Diaz J, Pilon C, Martres MP, Giros B, Souil B, Schott D, Morgat JL, Schwartz JC (1992) Identification, characterization, and localization of the dopamine $\mathrm{D}_{3}$ receptor in rat brain using $7-\left[{ }^{3} \mathrm{H}\right]$ hydroxy- $N-N$-di- $n$-propyl-2-aminotetralin. Proc Natl Acad Sci USA 89:8155-8159.

Lipska BK, Weinberger DR (1993) Delayed effects of neonatal hippocampal damage on haloperidol-induced catalepsy and apomorphineinduced stereotypic behaviors in the rat. Dev Brain Res 75:213-222.

Lipska BK, Weinberger DR (1994) Subchronic treatment with haloperidol and clozapine in rats with neonatal excitotoxic hippocampal damage. Neuropsychopharmacology 10:199-205.

Lipska BK, Weinberger DR (1995) Genetic variation in vulnerability to the bchavioral cffects of neonatal hippocampal damage in rats. Proc Natl Acad Sci USA 92:8906-8910.

Lipska BK, Jaskiw GE, Chrapusta S, Karoum F, Weinberger DR (1992) Ibotenic acid lesion of the ventral hippocampus differentially affects dopamine and its metabolites in the nucleus accumbens and prefrontal cortex in the rat. Brain Res 585:1-6.

Lipska BK, Jaskiw GE, Weinberger DR (1993) Postpubertal emergence of hyperresponsiveness to stress and to amphetamine after neonatal 
excitotoxic hippocampal damage: A potential animal model of schizophrenia. Neuropsychopharmacology 9:67-75.

Marengo J (1994) Classifying the courses of schizophrenia. Schizophrenia Bull 20:519-536.

Meller E, Bohmaker K, Goldstein M, Basham DA (1993) Evidence that striatal synthesis-inhibiting autoreceptors are dopamine $\mathrm{D}_{3}$ receptors. Eur J Pharmacol 249:R5-R6.

Mittleman G, LeDuc PA, Whishaw IQ (1993) The role of D1 and D2 receptors in the heightened locomotion induced by direct and indirect dopamine agonists in rats with hippocampal damage: an animal analogue of schizophrenia. Behav Brain Res 55:253-267.

Murray AM, Ryoo HL, Gurevich E, Joyce JN (1994) Localization of dopamine D3 receptors to mesolimbic and D2 receptors to mesostriatal region of human forebrain. Proc Natl Acad Sci USA 91:11271-11275.

Niznik HB, VanTol HHM (1992) Dopamine receptor genes: new tools for molecular psychiatry. J Psychiatry Neurosci 17:158-179.

Paxinos G, Watson C (1986) The rat brain in stereotaxic coordinates, 2nd Ed. New York: Academic.

Roberts GW (1991) Schizophrenia: a neuropathological perspective. Br J Psychiatry 158:8-17.

Schmauss C, Haroutunian V, Davis KL, Davidson M (1993) Selective loss of dopamine $\mathrm{D}_{3}$-type receptor $\mathrm{mRNA}$ expression in parietal and motor cortices of patients with chronic schizophrenia. Proc Natl Acad Sci USA 90:8942-8946.

Schocmaker H (1993) [ $\left.{ }^{3} \mathrm{H}\right]-7$ OH-DPAT labels both dopaminc $\mathrm{D}_{3}$ receptors and $\sigma$ sites in the bovine caudate nucleus. Eur $\mathrm{J}$ Pharmacol 242:R1-R2.

Schwartz JC, Lévesque D, Martres MP, Sokoloff P (1993) Dopamine $\mathrm{D}_{3}$ receptor: basic and clinical aspects. Clin Neuropharmacol 16:295-114.

Shapiro RM (1993) Regional neuropathology in schizophrenia. Where are we? Where are we going? Schizophrenia Res 10:187-239.
Sibley DR, Monsma Jr FJ (1992) Molecular biology of dopamine receptors. Trends Pharmacol Sci 13:61-69.

Sunahara RK, Seeman P, Van Tol HHM, Niznik HB (1993) Dopamine receptors and antipsychotic drug response. Br J Psychiatry 163[Suppl 22]:31-38.

Svensson K, Carlsson A, Waters N (1994) Locomotor inhibition by the $\mathrm{D}_{3}$ ligand $\mathrm{R}-(+)-7-\mathrm{OH}-\mathrm{DPAT}$ is independent of changes in dopamine release. J Neural Transm 95:71-74.

Tang L, Todd RD, O'Malley KL (1994) Dopamine D2 and D3 receptors inhibit dopamine release. J Pharmacol Exp Ther 270:475-479.

Wallace DR, Booze RM (1995) Identification of D3 and signlla receptors in the rat striatum and nucleus accumbens using ( \pm )-7-hydroxy- $N, N$ di- $n-\left[{ }^{3} H\right]$ propyl-2-aminotetralin and carbetapentane. J Neurochem $64: 700-710$

Waters N, Svensson K, Haadsma-Svensson Smith MW, Carlsson A (1993) The dopamine D3-receptor: a postsynaptic receptor inhibitory on rat locomotor activity. J Neural Transm 94:11-19.

Waters N, Löfberg L, Haadsma-Svensson Svensson K, Sonesson C, Carlsson A (1994) Differential effects of dopamine D2 and D3 receptor antagonists in regard to dopamine release, in vivo receptor displacement and behaviour. J Neural Transm 98:39-55.

Weinberger DR (1987) Implications of normal brain development for the pathogenesis of schizophrenia. Arch Gen Psychiatry 44:66()-669.

Weinberger DR, Berman KF, Suddath R Fuller Torrey E (1992) Evidence of dysfunction of a prefrontal-limbic network in schizophrenia: a magnetic resonance imaging and regional cerebral blood flow study of discordant monozygotic twins. Am J Psychiatry 149:890-897.

Wilkinson LS, Mittleman G, Torres E, Humby T', Hall FS, Robbins TW (1993) Enhancement of amphetamine-induced locomotor activity and dopamine relcase in nucleus accumbens following excitotoxic lesions of the hippocampus. Behav Brain Res 55:143-150. 